\title{
FURTHER OBSERVATIONS ON ACID METABOLISM IN RHEUMATIC CHILDREN
}

BY

\author{
WILFRID W. PAYNE, M.B., B.S. \\ (From the Hospital for Sick Children, Great Ormond Street, London, and \\ Queen Mary's Hospital for Children, Carshalton.)
}

In a previous study ${ }^{1}$ of this subject, the urinary output of a normal, a rheumatic and an asthmatic group of children was studied. Unfortunately the environment of the normal control group differed from that of the other two groups. Dr. Gray Hill suggested that a group of rheumatic children existed at Queen Mary's Hospital, Carshalton, who were living under identical environmental conditions with the control group. This hospital is within a few miles of the Banstead residential school where the control group lived. The food supply for both is in the same administrative area of the Iondon County Council. The Hospital group had a somewhat higher ration of protein but otherwise the diets were similar. The time of year being of some importance especially when considering food supplies, the same period of time (November to April) was chosen. In the first rheumatic group at the Hospital for Sick Children the patients were all attending the out-patient department and were usually free from symptoms. At Queen Mary's Hospital the majority of the children in the group were well advanced in their convalescence, but a few with some degree of activity were included. An attempt has been made to gauge the effect of the degree of activity by further sub-division of the cases.

The same methods were adopted as before, but in addition in the first 100 cases the estimation of organic acid by simple titration as given by Peters and van Slyke ${ }^{2}$ was performed in order to determine the meaning of the ' non-phosphate acid' values obtained previously. It was found that this value was approximately half the actual organic acid value, 27.98 c.c. per 100 c.c. urine for the ' non-phosphate acid' value as compared with 51.25 c.c. for the Peters-van Slyke organic acid titration. The correlation coefficient indicated a good general agreement between the two sets of values, being $+\cdot 73 \pm \cdot 0036$, which suggests that the assumption that the ' non-phosphate acid' value gave an indication of the organic acid excretion was justified. 


\section{Results.}

The following table 1 gives the results obtained compared with the normal control group. The values in the earlier rheumatic group are also given.

TABLE 1.

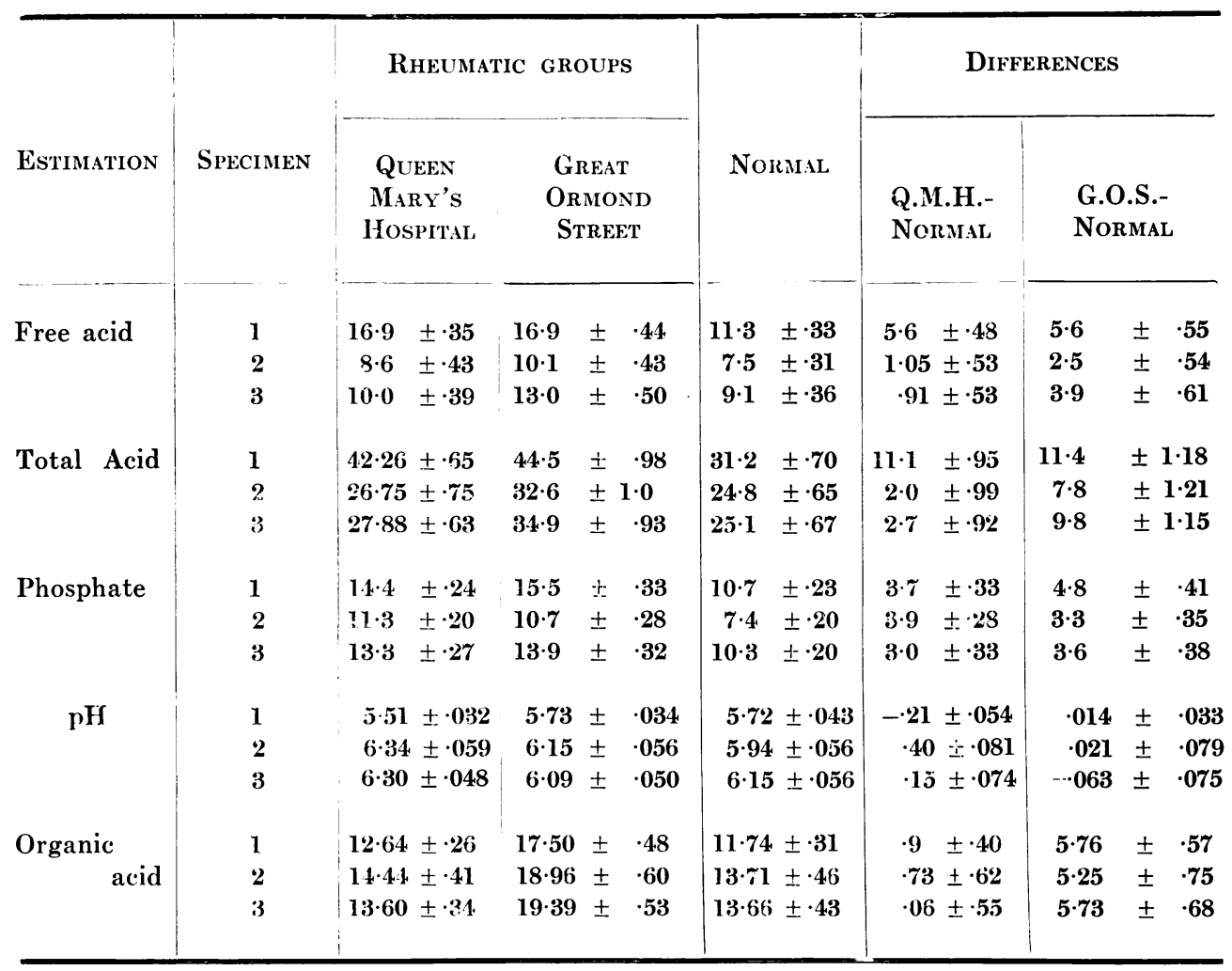

The first specimen (1) is passed on rising, the second (2) after breakfast, and the third (3) on going to bed. For further details as to methods of collection and analysis the previous paper' should be consulted.

It will be seen that the differences while present are not great. In the first morning specimen the free and total acid values are similar to the ' Great Ormond Street' values and show a definite difference from the control, but during the day the values approximate to the normal group. The increased phosphate output is again present to an almost similar degree. The difference in the organic acid values from the normal seen in the ' G.O.S.' series is not repeated, the Carshalton values being identical with the control group. On the other hand the $\mathrm{pH}$ which showed no difference in the 'G.O.S.' series from the normal, shows a barely significant increase 
in acidity in the first specimen, and a definitely significant increase in alkaline tide in the second specimen.

The following conclusions may be drawn:-(1) The first morning specimen reflects underlying diathesis, less influenced by diet. (2) The subsequent specimens are influenced to a great extent by diet. (3) There is an excess acid production in children suffering from rheumatism. (4) The excess of organic acid is largely of dietetic origin.

This increased output of acid may be due either to an inborn variation in the acid metabolism (the ' acid diathesis ') or to the effect of the rheumatic infection itself.

A subdivision of the Carshalton cases was made by Dr. Gray Hill into three groups (1) ' rheumatic heart disease,' (2) 'chorea' and (3) ' subacute rheumatism.' It was thought probable that the intensity of the rheumatic infection itself would be different in these three groups. The following table shows the results.

TABLE 2.

\begin{tabular}{|c|c|c|c|c|c|c|c|c|c|c|c|c|}
\hline \multirow{2}{*}{$\begin{array}{l}\text { Estimation } \\
\text { Free acid }\end{array}$} & \multirow{3}{*}{$\begin{array}{c}\text { Specimen } \\
\\
1 \\
2 \\
3\end{array}$} & \multicolumn{8}{|c|}{ Rheumatic Groups. } & \multicolumn{3}{|c|}{ TOTAL GROUP } \\
\hline & & & 1 & & & 2 & & 3 & & & & \\
\hline & & $\begin{array}{l}17 \cdot 08 \\
10 \cdot 2 \\
10 \cdot 11\end{array}$ & $\begin{array}{l} \pm \\
\pm \\
\pm\end{array}$ & $\begin{array}{l}\cdot 84 \\
.92 \\
\cdot 87\end{array}$ & $\begin{array}{c}18 \cdot 12 \\
8 \cdot 5 \\
10 \cdot 75\end{array}$ & $\begin{array}{rr} \pm & .74 \\
\pm & 1.12 \\
\pm & 1.03\end{array}$ & $\begin{array}{c}17 \cdot 2 \\
7 \cdot 3 \\
10 \cdot 77\end{array}$ & $\begin{array}{l} \pm \\
\pm \\
\pm\end{array}$ & $\begin{array}{l}.54 \\
.78 \\
.78\end{array}$ & $\begin{array}{c}16 \cdot 9 \\
8 \cdot 6 \\
9 \cdot 99\end{array}$ & $\begin{array}{l} \pm \\
\pm \\
\pm\end{array}$ & $\begin{array}{l}\cdot 35 \\
\cdot 43 \\
\cdot 39\end{array}$ \\
\hline $\mathrm{pH}$ & $\begin{array}{l}1 \\
2 \\
3\end{array}$ & $\begin{array}{l}5 \cdot 56 \\
6 \cdot 21 \\
6 \cdot 35\end{array}$ & $\begin{array}{l} \pm \\
\pm \\
\pm\end{array}$ & $\begin{array}{l}\cdot 08 \\
\cdot 12 \\
\cdot 11\end{array}$ & $\begin{array}{l}5 \cdot 53 \\
6 \cdot 27 \\
6 \cdot 51\end{array}$ & $\begin{array}{ll} \pm & \cdot 08 \\
\pm & \cdot 16 \\
\pm & \cdot 11\end{array}$ & $\begin{array}{l}5 \cdot 47 \\
6 \cdot 22 \\
628\end{array}$ & $\begin{array}{l} \pm \\
\pm \\
\pm\end{array}$ & $\begin{array}{l}\cdot 04 \\
\cdot 12 \\
\cdot 09\end{array}$ & $\begin{array}{l}5 \cdot 51 \\
6 \cdot 34 \\
6 \cdot 3\end{array}$ & $\begin{array}{l} \pm \\
\pm \\
\pm\end{array}$ & $\begin{array}{l}\cdot 032 \\
.059 \\
\cdot 048\end{array}$ \\
\hline $\begin{array}{l}\text { Organic } \\
\quad \text { acid }\end{array}$ & $\begin{array}{l}1 \\
2 \\
3\end{array}$ & $\begin{array}{c}13 \cdot 48 \\
14 \cdot 9 \\
13 \cdot 76\end{array}$ & $\begin{array}{l} \pm \\
\pm \\
\pm\end{array}$ & $\begin{array}{r}.70 \\
1.06 \\
.94\end{array}$ & $\begin{array}{l}13 \cdot 31 \\
14 \cdot 5 \\
14 \cdot 5\end{array}$ & $\begin{array}{rr} \pm & \cdot 64 \\
\pm & 1 \cdot 13 \\
\pm & 1 \cdot 10\end{array}$ & $\begin{array}{l}12 \cdot 63 \\
15 \cdot 12 \\
13 \cdot 46\end{array}$ & $\begin{array}{l} \pm \\
\pm \\
\pm\end{array}$ & $\begin{array}{l}\cdot 42 \\
.92 \\
\cdot 68\end{array}$ & $\begin{array}{l}12 \cdot 64 \\
14 \cdot 44 \\
13 \cdot 60\end{array}$ & $\begin{array}{l} \pm \\
\pm \\
\pm\end{array}$ & $\begin{array}{l}.26 \\
.41 \\
.34\end{array}$ \\
\hline
\end{tabular}

It will be seen that no sub-group differs from the main group by a significant amount. It may be concluded from this that there is an ' acid diathesis' in acute rheumatism in children.

\section{Summary.}

A further group of children under conditions more nearly similar to those of the control group of the previous communications has been examined with respect to their acid output. This group has been further 
divided into sub-groups of different types of infection. It is concluded that the morning specimen of urine is less influenced by diet and shows the existence of an ' acid diathesis.'

Thanks are due to Sir Frederick Menzies and Dr. Pugh for permission to carry out this investigation at the Queen Mary's Hospital, and to Dr. Gray Hill for pointing out the possibilities of this group of children and for the continued interest and trouble he has taken in selecting and grouping the children. This work would not have been possible without his help.

\section{REFERENGES.}

1. Payne, W. W., Arch. Dis. Childh., London, 1934, IX, 259.

2. Peters, J. P., \& Van Slyke, D. D., Quantitative Clinical Chemistry, Baltimore, 1932, II. 